\title{
Solving Incidents in Telecommunications Using a Multi-agent System
}

\author{
Lilyam Paolino \\ Facultad de Ingeniería \\ Universidad ORT \\ Montevideo, Uruguay \\ lilyam.paolino@gmail.com
}

\author{
Horacio Paggi \\ Facultad de Ingeniería \\ Universidad ORT \\ Montevideo, Uruguay \\ horacio.paggi@gmail.com
}

\author{
Fernando Alonso \\ Facultad de Informática \\ Universidad Politécnica de \\ Madrid \\ Madrid, España \\ falonso@fi.upm.es
}

\author{
Genoveva López \\ Facultad de Informática \\ Universidad Politécnica de \\ Madrid \\ Madrid, España \\ glopez@fi.upm.es
}

\begin{abstract}
The article presents el modelo e implementaciçon de a multiagent system fuzzy (SMAF), which allows the users to input fuzzy incidents $y$ determinar las relaciones de descendientes $y$ ascendientes entre ellos. SMAF acepta los incidents fuzzy with todas las imprecisiones de sus severity degree tal como lo expresan los usuarios. Tales impresiciones are translated into computational language and are recorded in a knowledge base. En primera instancia SMAF busca en su base de conocimientos entre los incidentes relacionados, las posibles soluciones del incidente planteado y se las sugiere al usuario. If in the first try there is not a solution, the search is expanded to the whole data base, analyzing and suggesting as possible solutions the ones of the incidents which have proximity or inclusion relationship with the original. Then the human experts must accept or reject the solutions suggested by the software agents. If there is no solution found, or if they are not confirmed, SMAF transfers the incident to an expert, human or software.
\end{abstract}

Keyword: multi-agent system, subject of an incident, incident, severities

\section{INTRODUCTION}

Some multi-agent systems based on intelligent agent interaction had the objective to find and suggest solutions to incidents which occurred in different areas. For example, when making the solution's decision in the administration of transport network [1], [2], when automating the industrial manufacturing process [3], in the fault diagnosis within electrical power[4], in telecommunication and Informatics services [5] or in the search of solutions to reinforce the networks' security [6].

SMAF is a multi-agent system, which is cooperative, heterogeneous in its structure and in the agents' functioning. It was tested in the telecommunication field, but it could also be used in other areas, for example, to incidents in the electronic commerce, knowledge management, medicine, etc., just by adapting the knowledge base. SMAF allows the input of fuzzy incidents expressed by the users with their natural vagueness and perceptions of the human language [7], [8], [9], recording them in a knowledge base through the quantification of the linguistics' imprecisions and searches in them all the possible solutions, without the analysis of their causes.

In SMAF the users can choose between working locally in a Server, which has the incidents and solutions within a database, or using mobile agents in different host of the network, which carry all the IPs directions of the issuer host, the destination and a reference of the concrete task which was asked.

Article layout: the Section II shows the related work. The Section III describes the SMAF model and Section IV describes agents' architecture. The Section V explains the funcionamiento del algoritmo mediante un ejemplo. Section VI shows the preliminary results Finally in section VII are presented the conclusions and possible future developments.

\section{RELATED WORK}

In the field of incidents detection and treatment in telecommunications, there are some commercial tools which suggest solutions to the incidents raised by the users [10]. En el area de los sistemas multiagentes relacionado con este tema existe poca investigación al respect. Existen sistemas multiagentes para la resolución de incidentes fuzzy en el tema de seguridad de las redes cuyo objetivo es crear un sistema de reacción y de decisión frente a alarmas provocadas por sensores, pero que no plantean register the incidents nor their severities expressed exactly as the user did [11]. Algunos modelos de sistemas multiagentes se avocan a capturar incidentes, pero sin consideración de sus soluciones. [12]. Otros models of multigent systems were designed to manage networks incidents, but without keeping in mind the participation of the final users when confirming or rejecting the proposed solutions [13]. 
Para SMAF el punto de arranque son aquellos eventos planteados por los usuarios para la búsqueda de sus soluciones, y que alteraran el normal funcionamiento de algún elemento dentro del área de telecomunicaciones, consideradando como incidentes fuzzy, en la acepción tal como se entiende en otras áreas, como Cobbit.

El sistema multiagente planteado pretende registrar los eventos que alteren el normal funcionamiento de algún elemento dentro de las comunicaciones, cualquiera sea el grado de gravedad especificado por los usuarios, manteniendo los grados de imprecisiones expresados por ellos y posteriormente buscar y sugerir sus posibles soluciones relacionando incidentes y generando una interacción entre agentes humanos y de software. Las soluciones sugeridas por SMAF se basan en la incertidumbre que generan las imprecisiones fuzzy[14], sin analizar las posibles causas, y serán confirmadas o rechazadas por los usuarios. Los agentes pueden, luego de haber sugerido una solución, poder encontrar otra mejor y hacer, dado el caso, una recomendación diferente al usuario que lo solicite.

\section{SMAF MODEL}

The SMAF model works with concepts of Subject, Incident and Severities. A subject is any component in which an incident may happen. Severity indicates the degree in which the incident may happen. Incidents are events which alter the subject's normal functioning. The incidents are identified by the subject, the event with its severities and the solutions (if there were any) and the reference of their children and ancestors.

The SMAF model describe the fuzzy incidents treatment through six kinds of agents: GUIUserAgent, GUIAdministratorAgent, SubjectAgent, IncidentAgent, SearchAgent, and DataAcessAgent. Among these,

GUIUserAgent and GUIAministratorAgent are interface agents which interact with the other agents, humans and software. SubjectAgent and IncidentAgent are the data treatement agents to release, modify, eliminate the subject and theirs incidents and severities. SearchAgent are the process agents, specialized in the search for the incidents' solutions. DataAccessAgents are dedicated to access the database to get or input information (Fig.1, 1.,2., 3.,4.,5.,6.,7.,) SMAF agents are semi-autonomous, because they can act by themselves o a solicitud de human or software agent. They can easily integrate new incidents and severities and adapt to the environment changes. Por ejemplo, if the IncidentAgent has no record of the subject, , it can ask for the missing element, but it can also act if the human agent inputs a new subject. The IncidentAgent, reads the knowledge base by itself and if it finds a better solution it can update the responses. It is natural for these software agents to work with distributed systems and transfer only the necessary knowledge in order to fulfill of the task [15].

In order to treat the incidents, the IncidentAgents receives from the GUIUserAgent the new incident's data, it validates it and translates it into subintervals of linguistic variables by the application of the formula:

Sub-interval $=\left[i^{*}(10 /\right.$ total $),(i+1) *(10 /$ total $\left.)\right]$

Where $\boldsymbol{i}$ is the current position and total is the amount of available intervals for each incident. SMAF assumes that the scale for severity for each incident is 0 (severidad minima) to 10 (severidad maxima). If the formula were applied to the 'network speed' as the subject, its severities intervals (which are in descending order, according to their impact on the subject), would be 'too low' [7.5, 10], "low" [5, 7.5], "a little low" [2.5, 5] and "casi normal" $[0,2.5]$. The incidents, their sub-intervals and their respective severities are encoded by equation (1), stored in a database and later they are presented in a graph which shows the relation between them.

When the user searches a solution for an incident, the SearchAgent interacts with the GUIUserAgent, receiving the incident and searching it within the graph whether the given incident has got a solution, or there is an incident whose severity contains in its range the given incident or the solution is near it. The agent interacts with the user taking his requirements, notifying the solutions found and asking him for confirmation.

The cooperation among agents makes the search for solutions much faster, through the transfer of knowledge. E.g. The DataAccessAgent transfers to the IncidentAgent all the information that it needs from the database so to find the best solutions to the incident.

\section{AGENTS ARCHITECTURE}

In SMAF the agents can be compounded by other agents, following a hierarchic structure. For example, the IncidentAgent has its identification, lists with all the parents and children incidents, the severities encoded and the solutions (if there were any). The incidents can be compound by 0,1 , or more children and 0,1 , or more parents. The children incidents, called sub-incidents, can be whether 'obligatory' or 'non obligatory', 'binary' or 'non binary'. The 'obligatory' are the ones that for the occurrence of one incident, all the incidents of the hierarchy must happen. In the example 'the network does not work' a subincident might be 'not possible to connect to Internet' and for 'non obligatory' 'the router's lights do not work'. The 'binary' are the ones that admit only two values, without the consideration of severities, por ejemplo : 'the router works' or 'the router does not work'. The human agent is who sets the incidents and who wants solutions from the system, they interact with GUIUserAgent (Fig.1). The agents communicate through messages, which can be accepted or rejected. For example, the IncidentAgent can reject a message of releasing if the subject is not valid, or the SearchAgent can refute a message that asks for the search of an incident's solution of it not congruent with the database.

\section{FUNCIONAMIENTO DEL ALGORITMO MEDIANTE UN EJEMPLO}


To show how the algorithm works, los agentes humanos plantearon diferentes incidentes en diferentes elementos, con sus gravedades, como se muestra en los campos "Subject", "Incidents", and "Severities" de la tabla 1. Los subjects de los incidentes se codificadan secuencialmente, según orden en que fueron ingresados y las gravedades de los incidentes, mediante la equation 1 , como muestra el campo "Codificación” de la tabla 1. mediante la fórmula 1. SMAF codifica los subject según su orden secuencial de ingreso. Para los routers, por ejemplo, el primer subject de la tabla, con el incidente "funciona" y la gravedad "regular", le corresponde el intervalo 0,3. Para el mismo sujeto, con gravedad "mal”, el intervalo correspondiente es de 3,7, y para la gravedad "muy mal”, su intervalo es 7,10.

TABLE 1. Algunos ejemplos ingresados y codificados para testear el funcionamiento del sistema.

\begin{tabular}{|c|c|c|c|}
\hline $\begin{array}{l}\text { Subject } \\
\text { (expresados } \\
\text { por } \\
\text { Usuario) } \\
\end{array}$ & $\begin{array}{l}\text { Incidents } \\
\text { (expresados } \\
\text { por } \\
\text { Usuario) } \\
\end{array}$ & $\begin{array}{l}\text { Severities } \\
\text { (expresados por } \\
\text { Usuario) }\end{array}$ & $\begin{array}{l}\text { Codificación } \\
\text { (aplicando } \\
\text { equation 1). }\end{array}$ \\
\hline Router & Funciona & Regular,mal,muy mal & $\begin{array}{l}\mathrm{A}(0,3-3,7- \\
7,10)\end{array}$ \\
\hline Network & Speed & Baja, muy baja & $\mathrm{B}(0,5-5,10)$ \\
\hline IP-protocols & Funcionan & $\begin{array}{l}\text { Regular,algo mal, } \\
\text { mal, muy mal, } \\
\text { excesivamente mal) }\end{array}$ & $\begin{array}{l}\text { C }(0,2-2,4- \\
4,6-6,8- \\
8,10)\end{array}$ \\
\hline Bandwidth & Se configuró & $\begin{array}{l}\text { Algo insuficiente, } \\
\text { insuficiente, muy } \\
\text { insuficiente, } \\
\text { excesivamente } \\
\text { insuficiente }\end{array}$ & $\begin{array}{l}\mathrm{D}(0,3-3,5- \\
5,8-8,10)\end{array}$ \\
\hline Gateways & Funcionan & $\begin{array}{l}\text { A veces mal, } \\
\text { frecuentemente mal, } \\
\text { siempre mal, , a veces } \\
\text { mal, a veces muy mal, } \\
\text { frecuentemente muy } \\
\text { mal, siempre muy mal }\end{array}$ & $\begin{array}{l}E(0,2-2,3- \\
3,5-5,7-7,8 \\
-8,10)\end{array}$ \\
\hline $\begin{array}{l}\text { Knowledge } \\
\text { managemen } \\
\mathrm{t}\end{array}$ & $\begin{array}{l}\text { Usado } \\
\text { para } \\
\text { solucionar } \\
\text { incidentes }\end{array}$ & $\begin{array}{l}\text { Frecuentemente, } \\
\text { a veces, } \\
\text { raramente, nunca }\end{array}$ & $\begin{array}{l}F(0,3-3,5 \\
-5,8- \\
8,10)\end{array}$ \\
\hline Manuals & $\begin{array}{l}\text { Accesibili } \\
\text { dad }\end{array}$ & $\begin{array}{l}\text { A veces, rara vez, } \\
\text { nunca }\end{array}$ & $\begin{array}{l}\mathrm{G}(0,3- \\
3,7-7,10)\end{array}$ \\
\hline Hosts & Caen & $\begin{array}{l}\text { Aguna vez, } \\
\text { frecuentemente }\end{array}$ & $\begin{array}{l}\mathrm{H}(0,5- \\
5,10)\end{array}$ \\
\hline $\begin{array}{l}\text { User 's } \\
\text { capacitation }\end{array}$ & Funciona & $\begin{array}{l}\text { Bien, a veces } \\
\text { bien, raramente } \\
\text { bien, mal, a veces } \\
\text { muy mal, } \\
\text { siempre muy mal }\end{array}$ & $\begin{array}{l}\text { I }(0,2-2,3 \\
-3,5-5,7 \\
-7,8- \\
8,10)\end{array}$ \\
\hline $\begin{array}{l}\text { Personal } \\
\text { Communica } \\
\text { tions } \\
\text { between } \\
\text { Experts and } \\
\text { users }\end{array}$ & Funciona & $\begin{array}{l}\text { A veces bien, } \\
\text { raramente bien, } \\
\text { mal, a veces muy } \\
\text { mal, siempre } \\
\text { muy mal }\end{array}$ & $\begin{array}{l}\mathrm{J}(0,2-2,4 \\
-4,6-6,8 \\
-8,10)\end{array}$ \\
\hline
\end{tabular}

Cuando el usuario realiza una búsqueda de soluciones a algún incidente, SMAF genera un grafo (Fig. 2) con los incidentes que podrían contener soluciones al incidente originario.. Por eso en dicho grafo no aparecen todos los incidentes de Tabla 1, puesto que para armar el grafo solo se tiene en cuenta los candidatos a ser la resolución como búsqueda de soluciones, y aparecen otros incidentes que no están en Tabla 1, por habérselos ingresado relacionados a otras gravedades.

If a user searches the solutions for 'IP protocols funcionan regular', which is quantified by equation (1) as: $\mathrm{C}(0,2)$ and 'Manuales son comprensibles a veces', quantified by equation (1)as $\mathrm{E}(0,2)$, SMAF searches in the graph for those incidents that contain the wanted incidents. It finds the following incidents: C $(0,4)$ " which contains the incident C $(0,2)$ ", and the incident E $(0,3)$ " which contains the incident $\mathrm{E}(0,2)$ ". SMAF gets two new set of incidents, they are named "IP-ProtocolsSet" and "GatewaySet". "IPProtocolsSet" consists of all incidents in the graph with a relationship of ancestor or children to the original incident $\mathrm{C}(0,2)$ ") and C $(0,4)$ ”.

The distance between each 'IP-ProtocolsSet' is calculated in relation to $C(0,2)$, as it is used in other collaborative systems [14]. The SMAF distance is the distance between the node with the wanted solution and each of the children or parents found in a candidate set, then those distances are elevated to the second power and finally summed. If the distance for an input incident is 0 , the distance to its child, would be 1 , to its grandchild 2 , to its great grandchild 3.

So the total distance from the incident to its great grandchild would be $1^{2}+2^{2}+3^{2}=14$. The total distance entre el nodo originario y los nodos candidatos are calculated como la suma de los cuadrados de las distancias entre los candidatos y el original. Los cálculos al cuadrado es para penalize the distances that are too apart from each other, puesto que si las distancias fueran cortas y si hubieran muchos candidatos, las diferencias para determinar la mejor solución serían imperceptibles. Also, there weren’t considered the calculations based on potencies greater than a square, because that could mean an excessive ponderation of the lower distance criteria, and other criteria as inclusion.

"IP-ProtocolsSet" is composed by: $\mathrm{C}(0,2), \mathrm{C}(0,4)$ with distance $0, \mathrm{H}(5,10)$ parent of $\mathrm{C}(0,4)$ with distance $1, \mathrm{~B}$ $(5,10)$ parent of $H(5,10)$ with distance 2 , E $(7,10)$ parent of $\mathrm{H}(5,10)$ with distance $2, \mathrm{~A}(0,3)$ parent of $\mathrm{E}(7,10)$, with distance 3 , C $(0,2)$ parent of $\mathrm{E}(7,10)$ with distance $3, \mathrm{~B}$ $(0,5)$ parent of $C(0,4)$ with distance $1, F(0,5)$ parent of $C$ $(0,4)$ with distance $1, \mathrm{~J}(2,4)$ parent of $\mathrm{F}(0,5)$ with distance 2 , A $(7,10)$ parent of $\mathrm{F}(0,5)$ with distance 2 .

"GatewaySet" consists of all incidents in the graph with a ancestors or children relationship E $(0,2)$ and $E(0,3)$ with 
distance 0 , and it is compound by: $\mathrm{E}(0,2), \mathrm{E}(0,3), \mathrm{I}(0,3)$ because it is the parent of $\mathrm{E}(0,3)$ with distance $1, \mathrm{~A}(7,10)$ because it is the parent of $\mathrm{E}(0,3)$ with distance $1, \mathrm{D}(3,8)$ because it is the parent of I $(0,3)$ with distance 2 , A $(0,3)$ because it is the parent of $\mathrm{D}(3,8)$ with distance $3, \mathrm{~F}(3,5)$ because it is the parent of $A(7,10)$ with distance $2, C(0,2)$ because is the parent of $\mathrm{F}(3,5)$ with distance $3, \mathrm{~B}(0,5)$ because it is the parent of $\mathrm{E}(0,2)$ with distance $1, \mathrm{G}(3,7)$ because it is the parent of $\mathrm{B}(0,5)$ with distance 2 .

IP-ProtocolsSet and GatewaySet are two feasible candidate sets, which could contain the incidents' solutions to solve the users' incidents. To search it, SMAF performs the intersection of IP-ProtocolsSet and GatewaySet, the results of this intersection are: $\mathrm{C}(0,2)$ with distance $9\left(0^{2}+3\right.$ $\left.{ }^{2}\right)$, B $(5,10)$ with distance $8\left(2^{2}+2^{2}\right)$, A $(0,3)$ with distance $18\left(3^{2}+3^{2}\right), C(0,2)$ with distance $18\left(3^{2}+3^{2}\right), B(0,5)$ with distance $2\left(1^{2}+1^{2}\right), \mathrm{F}(3,5)$ with distance $8\left(2^{2}+2^{2}\right)$, A $(7,10)$ with distance $5\left(2^{2}+1^{2}\right)$.

In order to poderate the best solution, SMAF puts the intersections in ascending order according to their distances. The new set consists of : $\mathrm{B}(0,5)$ distance $2, \mathrm{~A}(7,10)$ distance 5 , B $(5,10)$ distance $8, G(3,7)$ distance $8, C(0,2)$ distance 9 , $\mathrm{A}(3,5)$ distance $18, \mathrm{C} 18$. The user is asked for confirmation

TABLE 2 - First Case- Results Solutions for $\mathrm{C}(0,2)$ and $\mathrm{E}(0,2)$ are seek

\begin{tabular}{|l|l|l|}
\hline $\begin{array}{l}\text { Incident } \\
\mathrm{C}(0,2) \\
\mathrm{E}(0,2)\end{array}$ & $\mathrm{D}$ & $\begin{array}{l}\text { User } \\
\text { Satisfa } \\
\text { ction }\end{array}$ \\
\hline $\mathrm{B}(0,5)$ & 2 & $100 \%$ \\
\hline $\mathrm{A}(7,10)$ & 5 & $100 \%$ \\
\hline $\mathrm{B}(5,10)$ & 8 & $80 \%$ \\
\hline $\mathrm{F}(3,5)$ & 8 & $90 \%$ \\
\hline $\mathrm{G}(3,7)$ & 8 & $50 \%$ \\
\hline $\mathrm{C}(0,2)$ & 9 & $30 \%$ \\
\hline $\mathrm{A}(0,3)$ & 18 & $30 \%$ \\
\hline $\mathrm{C}(0,2)$ & 18 & $30 \%$ \\
\hline
\end{tabular}

TABLE 4- Third Case - Results

Solutions for I $(0,2)$ are seek

\begin{tabular}{|l|l|l|}
\hline $\begin{array}{l}\text { Incident } \\
\mathrm{I}(0,5)\end{array}$ & $\mathrm{D}$ & $\begin{array}{l}\text { User } \\
\text { Satisfa } \\
\text { ction }\end{array}$ \\
\hline $\mathrm{I}(0,3)$ & 1 & $90 \%$ \\
\hline $\mathrm{C}(4,8)$ & 1 & $100 \%$ \\
\hline $\mathrm{D}(3,8)$ & 2 & $50 \%$ \\
\hline $\mathrm{E}(0,3)$ & 2 & $90 \%$ \\
\hline $\mathrm{A}(0,3)$ & 2 & $90 \%$ \\
\hline $\mathrm{E}(7,10)$ & 3 & $80 \%$ \\
\hline $\mathrm{I}(0,3)$ & 4 & $50 \%$ \\
\hline $\mathrm{F}(3,8)$ & 4 & $50 \%$ \\
\hline
\end{tabular}

(D : Distance) Se calculó la media en base a la suma de los porcentajes de satisfacción explícita de los usuarios, divida por la cantidad de incidentes considerados como candidatos de of the new solutions which may or may not solve the original problem. If the user confirms it, the solution is stored in the incident data base, saved within the same execution. If all the possible solutions are presented but they do not solve the problem, SMAF sends the case to an expert user.

\section{PRELIMINARY RESULTS}

SMAF was tested and the technology used was JADE. The system's performance can be measured by the relation between the number of correct responses and the total number of requests. It was considered correct all the solutions confirmed by the user who set the original incident. I.e. some of the obtained results are shown. First Case: they ask for answers which can cover more than one incident, bearing in mind the 'IP family protocols that sometimes funciona regulart' quantifying it as $C(0,2)$ and 'Sometimes unreachable Getaway', E $(0,2)$. So the following values are obtained (1) (Table 2). In the Second Case (Table 2), the solution to only one incident is searched, quantifying it as $\mathrm{F}(3,5)$. The Third Case (Table 3$)$, searches for solutions to I $(0,5)$. Fourth Case (Table 4$)$ : searches the solutions for $\mathrm{B}(5,10)$

TABLE 3- Second Case- Results

Solutions for $\mathrm{F}(3,5)$ are seek

\begin{tabular}{|l|l|l|}
\hline $\begin{array}{l}\text { Incident } \\
F(3,5)\end{array}$ & D. & $\begin{array}{l}\text { User } \\
\text { Satisfa } \\
\text { ction }\end{array}$ \\
\hline $\mathrm{F}(0,5)$ & 0 & 100 \\
\hline $\mathrm{C}(0,2)$ & 1 & $100 \%$ \\
\hline $\mathrm{A}(7,10)$ & 1 & $90 \%$ \\
\hline $\mathrm{A}(3,7)$ & 1 & $90 \%$ \\
\hline $\mathrm{E}(7,10)$ & 1 & $80 \%$ \\
\hline $\mathrm{J}(2,4)$ & 1 & $90 \%$ \\
\hline $\mathrm{G}(3,7)$ & 2 & $80 \%$ \\
\hline $\mathrm{H}(5,10)$ & 3 & $50 \%$ \\
\hline $\mathrm{G}(0,3)$ & 2 & $50 \%$ \\
\hline
\end{tabular}

TABLE 5 - Fourth Case : Results. Solutions for B(5,10) are seek

\begin{tabular}{|l|l|l|}
\hline $\begin{array}{l}\text { Incident } \\
\mathrm{B}(5,10)\end{array}$ & D & $\begin{array}{l}\text { User } \\
\text { Satisfa } \\
\text { ction }\end{array}$ \\
\hline $\mathrm{I}(0,3)$ & 1 & $100 \%$ \\
\hline $\mathrm{H}(5,10)$ & 1 & $90 \%$ \\
\hline $\mathrm{J}(2,4)$ & 2 & $80 \%$ \\
\hline $\mathrm{J}(2,6)$ & 2 & $80 \%$ \\
\hline $\mathrm{I}(0,5)$ & 2 & $90 \%$ \\
\hline $\mathrm{F}(3,8)$ & 2 & $70 \%$ \\
\hline $\mathrm{C}(0,4)$ & 2 & $60 \%$ \\
\hline $\mathrm{E}(0,3)$ & 3 & $40 \%$ \\
\hline
\end{tabular}

soluciones. The possible conclusions according to these results are: In the first case, the user's satisfaction media was $63.75 \%$ ( 510/8, siendo 510 la suma total de los porcentajes de satisfacciones y 8 la cantidad de incidents, en el primer caso ); in the Second Case it was $81.1 \%$ ( 730 / 9). In the third Case 
it was $75 \%$ (600/8) and in the fourth case it was $76.25 \%$ (610 / 8). When more than one case was contemplated, the result was the lowest satisfaction (case 1). The highest satisfaction results were obtained when the solutions belonged to the incidents within the original one or when the distances were respect to the original incident (case 2). Lower were found when the distances were larger with respect to the original incident (case 3). The trend of the four cases was rectified with 25 other input cases.

\section{CONCLUSIONS AND FUTURE WORK}

The multi-agent system, SMAF, was designed and developed to search solutions to fuzzy incidents of a subject that were raised by users with different severities. This system works cooperatively with users searching for solutions to incidents. SMAF tries to automate the resolution of incidents fuzzy in communications. The human actor interacts all the time with the agents: in the passage of requirements, confirming or rejecting the solutions found by SMAF, learning the found solutions. Users` requirements are taken as they were expressed, in natural language (originally Spanish) admitting that they are expressed with different degrees of imprecisions and perceptions that can not be represented by classical logic.
The solutions found can be supplanted by new solutions, if the agents find another which is better, so that the system is easily adaptable to improvements, if the user thinks it, according to the system administrator. SMAF was developed using JADE as techonology and it was tested in the field of telecommunications, but it would be used in others areas because it was designed and developed fully parameterized and with a philosophy to be easily adapted to the needs of any users, for that the only requirement is to change the data base.SMAF manages the search of solutions by agents working cooperatively among themselves, by the local level and a distributed form across different host in the computer network, allowing the user the choice of a way of work. Possible improvements: enlarge the amount of servers with different solutions in order to evaluate more deeply the selection criteria, when searching for solutions it is thought to prioritize the obligatory sub-incident to the original incident and the binary ones, if there were any. Now a days it is treated in the telecommunication field in a local network, or interconnected local networks, but it wasn't evaluated in the 'Internet's world', its performance is unknown, but it will be tried in future stages. La comunicación entre los agentes, efectuada en esta versión mediante mensajes, se piensa desarrollar mediante un protocolo entendible por ellos.

Figure 1 - Interaction between agents and agents with processes.

The arrows show the connection between processes, the

lines show the expert agents in each

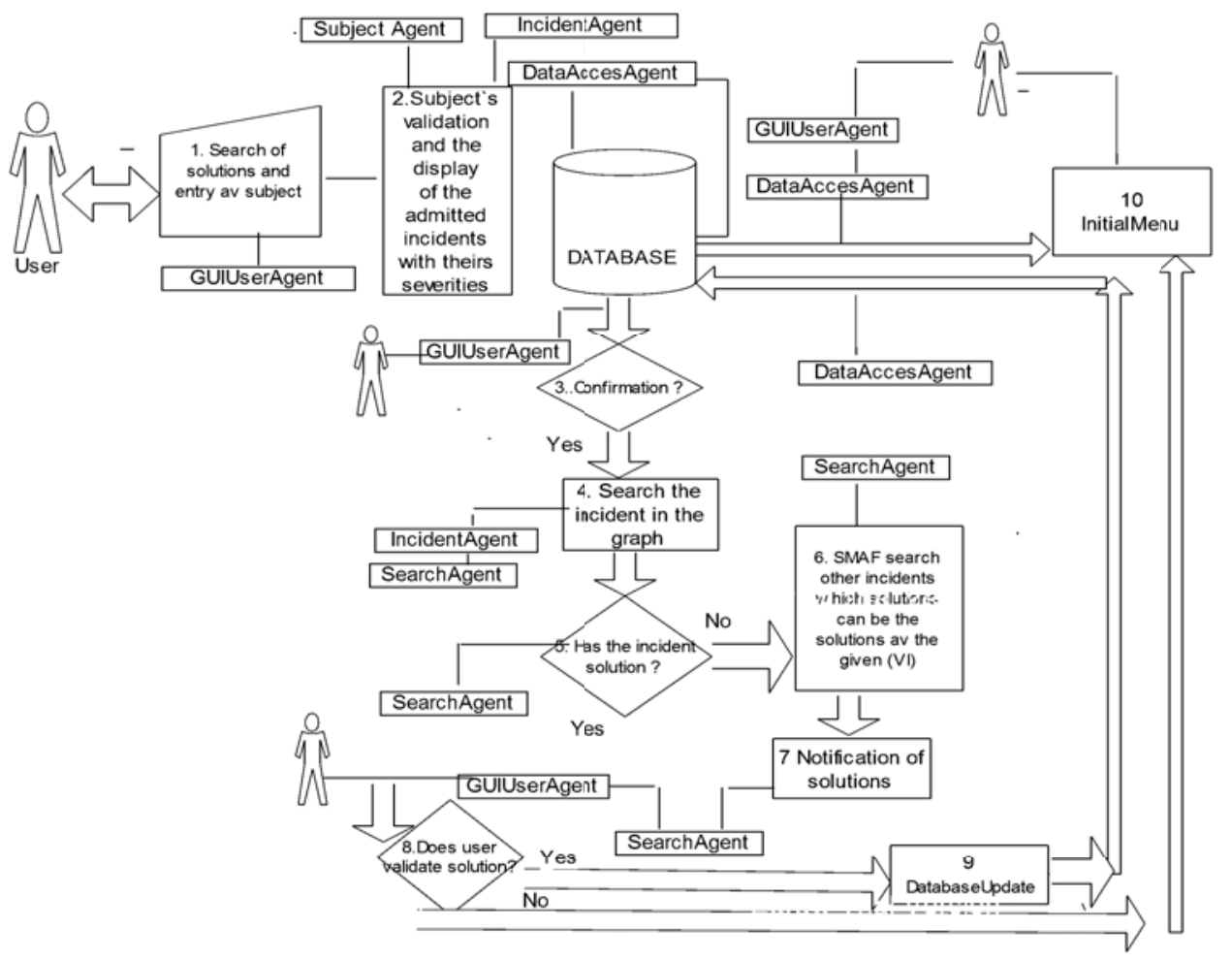




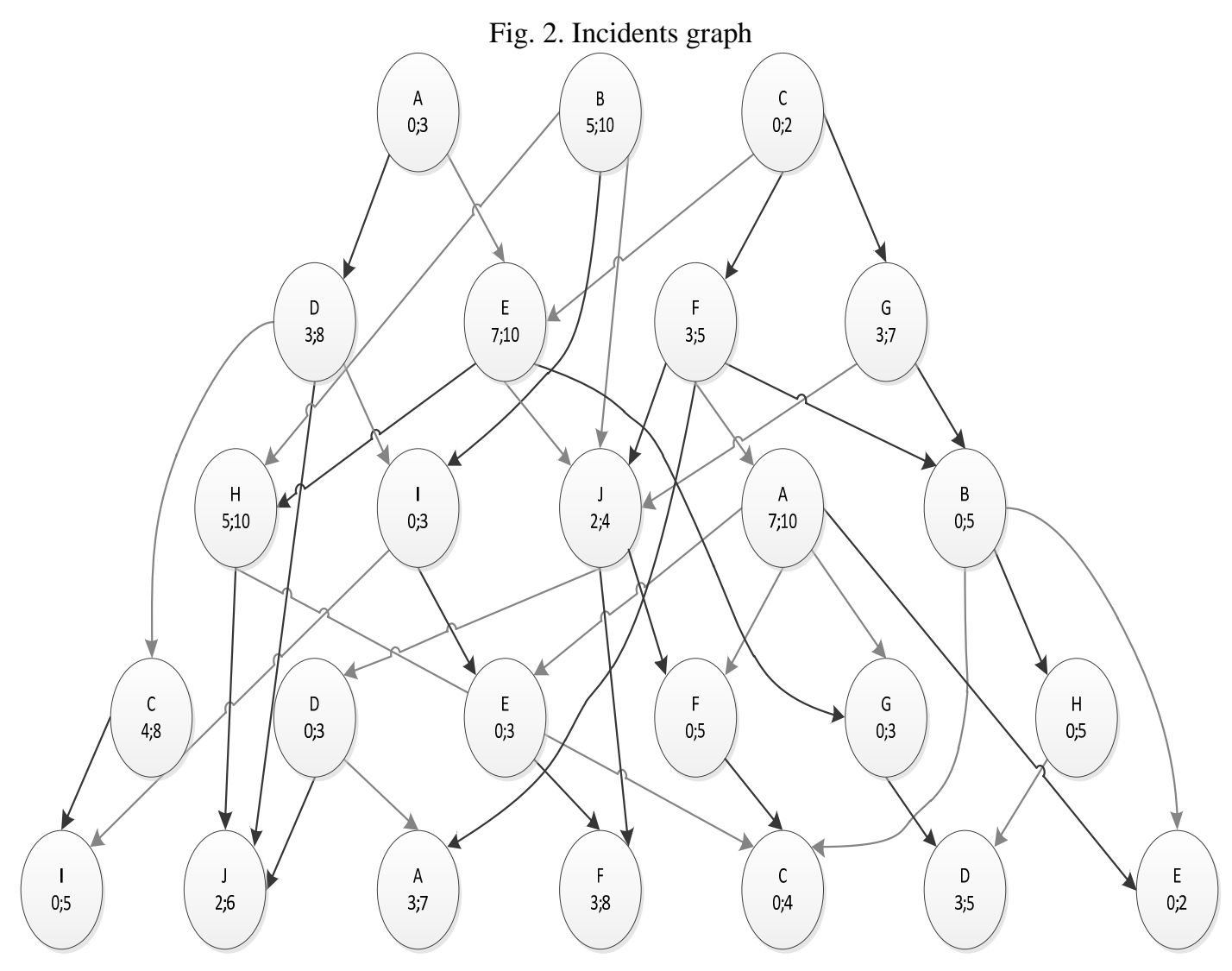

Fig. 2. Incidents Graphs.

\section{REFERENCES}

[1] D Rahal, F. Rahal, M. Reda Chekroun, "Multi agent system for modeling transport systems” in European Journal of Scientifisc Research”, M2SC Laboratory civil engineeringdepartment USTO University Oran Algeria, ISSN 1450-216X Vol.46 Nro 1 (2010), pp. 080-089, EuroJournals Publishing, Inc. 2010

[2] K. Bouamrane, C.Tahon, B. Beldijilali, “ A making -decision system for an urban transportation network”, in Journal of Computer Science $\S$ Techonology, october 12005

[3] B.J.Botti, Navarro, A. Giret Boggino, “A multiagent Methodology for Holonic manufacturing systems “, series : Stringer Series in Advanced Manufacturing, XVI ,214 P, 2008

[4] S.D. J.McArthur, E.M. Davidson, J.A. Hossak, J.R.McDonald, "Automating power system fault diagnosis through multiagent system technology”, Hawai international conference on system science, vol 2 pp 20059a, Proceedings of the 37th. Annual Hawaii International Conference on System Sciences (HICSS'04) - Track2, 2004

[5] T. Walkowiak, T.Wilk, “ Incident detection analysis in communication and information systems fuzzy logic”, in Dependability of Computer Systems, International Conference on, pp.205-212, $2^{\text {nd }}$ International Conference on Dependability of Computer Systems(DepCos-Relcomex 07), 2007

[6] D.Horfan Alvarez, A.M.Bailey, L.A. Gomez Blandón, University of Antioquia,"System of security in local network using distributed systems agents”, Journal of Facultet of Ingeniery. Nro. 34, pp 101113, september 2005

[7] K.Atanassov "Intuitionistic fuzzy sets: past, present, and futur", "Fuzzy Sets and Systems “, vol 31, pag. 343-344, 2003

[8] J.M.Mendel and W.Dongriu, "Computing with words for hiearchical and distributed decision making ", Ch. 9 in Computational Intelligence in Complex Decision Systems, Atlantic Press, 2009
[9] W. Dongriu , “A brief tutorial on interval type2 fuzzy sets and systems”, http://www.linkedln.com/in/dongruiwu

[10] Xperta.hhtp://www.asca.as /

[11] C-Edric Bonhomme, C. Feltus, D. Khadraoui, Centre for IT Innovation, Public Research Centre Henri Tudor, Luxembourg, Cedric .bonhomme@tudor.lu, “A multi-agent based decision mechanism for incident reaction in telecommunication network ", in Computer Systems and Applications (AICCSA) 2010 IEEE/AC International Conference.ISBN : 978-1-4244-7716-6

[12] J. Aguilar, B. Abrahm, Cemisid, Departamento de Computación, Facultad de Ingeniería, Universidad de Los Andes, La Hechicera, Mérida., "Security incidents management systems based on multiagent systems"; in Proceedings the 13th WS EAS International Conference on Computers Science, 1996

[13] M.C.De Gennaro, A. Jadbabaie, "Formation control for a cooperative multi-agent system using decentralized navigation functions”, in IEEEExplorer.ieee.org, Conferences, American COntrol COnferences, 2, 2006

[14] Zadeh, L. (1973) 'Outline of a new approach to the analysis of complex systems and decision processes', IEEE Transactions on Systems, Man and Cybernetics

SMC-3, 28-44.

[15] D.D.Steiner , "Imagine : an integrated environment for construction distributed artificial intelligence systems " in G.M.P. Ochare, N.R.Jennings (ed.) foundations of Distributed Artificial Intelligence, pp.345-364. Jhon Wiley and sons. 1996 
